\title{
RADIOCARBON VARIABILITY IN GROUNDWATER IN AN EXTREMELY ARID ZONE-THE ARAVA VALLEY, ISRAEL
}

\author{
Avihu Burg ${ }^{1,2} \bullet$ Michael Zilberbrand $^{3}$ - Yoseph Yechieli ${ }^{1}$
}

ABSTRACT. Radiocarbon values of groundwater in main aquifers of the extremely arid Negev Desert and the Arava Valley, southern Israel, are used for studying the underground flow regime, particularly the complex connections between different aquifers and mixing of water bodies. The study shows that ${ }^{14} \mathrm{C}$ can serve as a hydrological tracer in arid environments and that groundwater dating may be possible (although not very accurate) even in this extremely arid environment (precipitation, $<50 \mathrm{~mm} / \mathrm{yr}$ ), where there is almost no vegetation. There are several aquifers in this region, some of which are deep (deeper than $500 \mathrm{~m}$ ) and regional and contain mainly fossil water, while others are local and restricted to the Arava, much shallower (50-200 m) and are thought to contain historical to recent waters. Most of the current recharge to these shallow unconsolidated aquifers comes from flash floods that flow from the mountains rising on both sides of the valley. The groundwater in the deep aquifers has low ${ }^{14} \mathrm{C}$ values (usually $<5 \mathrm{pMC}$ ), implying old ages (preliminary ages $>26,000 \mathrm{yr}$ ). Groundwater in the shallow aquifers characterized by higher ${ }^{14} \mathrm{C}$ values (up to 60-70 pMC) imply younger ages and faster groundwater flow (recent recharge). This is also supported by the presence of tritium in some of the samples. A few exceptional values are explained by the unique mixing of water from different sources; another is due to a technical failure in the well.

\section{INTRODUCTION}

Radiocarbon is the most accessible and widely used technique for dating groundwater resources (e.g. Vogel 1970; Mook 1980; Fontes 1983), although it is strongly influenced by water-rock interactions (Kroitoru et al. 1989; Clark and Fritz 1997). Therefore, ${ }^{14} \mathrm{C}$ age estimations of groundwater should be interpreted very cautiously, followed by a wide suite of geochemical and isotopic data in order to correct the measured ${ }^{14} \mathrm{C}$ activities for the geochemical processes in the aquifer (e.g. Mook 1980; Fontes 1983). One of the common methods for calculating groundwater ages, which takes into consideration the processes of water-rock interaction, is with geochemical computer codes, such as NETPATH (Plummer et al. 1991). Mixing of several water bodies having different ${ }^{14} \mathrm{C}$ activities is a limiting factor for dating. Nevertheless, ${ }^{14} \mathrm{C}$ can be used for identifying the sources of different water bodies even if the absolute dating is problematic.

In temperate and Mediterranean regions, the activity of ${ }^{14} \mathrm{C}$ decreases from the topsoil, where the carbon values are modern, to the groundwater, mainly due to 2 processes: water-rock interaction in the unsaturated zone and radioactive decay in the aquifer. In arid regions, the soil cover is much less developed due mainly to the sparse vegetation; thus, it is poor in organic matter and low in $\mathrm{CO}_{2}$. These unique conditions make the efficiency of ${ }^{14} \mathrm{C}$ dating in arid zones more ambiguous. That is, it is not clear whether the basic rules for groundwater dating are the same as in Mediterranean and temperate regions and/or whether commonly used methods for $\mathrm{A}_{0}$ estimation are acceptable.

The objective of the current research is to examine whether, despite the difficulties in groundwater ${ }^{14} \mathrm{C}$ dating in arid zones, it is still possible to obtain reliable, albeit preliminary, ages and to use ${ }^{14} \mathrm{C}$ data in order to distinguish between different major aquifers and their sources of water. Moreover, since the amount of current recharge is small, the range of ${ }^{14} \mathrm{C}$ ages is wider compared to that in temperate regions, thus making it a useful hydrological tool for better understanding the recharge processes in this arid area.

\footnotetext{
${ }^{1}$ Geological Survey of Israel, 30 Malkhe Israel St., Jerusalem 95501, Israel.

${ }^{2}$ Corresponding author. Email: burg@gsi.gov.il.

${ }^{3}$ Israeli Water Administration, Hydrological Service, P.O. Box 36118, Jerusalem 91360, Israel.
} 


\section{A Burg et al.}

\section{STUDY AREA}

The Arava Valley is located in the southern region of Israel (Figure 1a), and is part of the arid belt of the Northern Hemisphere. The valley, shared by Israel and Jordan, is bounded by mountains on both sides (Figure 1a), the Negev Highlands to the west, which are built mainly of carbonate rocks, and the Edom Mountains to the east, which are built mainly of crystalline rocks. Alluvial fans accumulate at the foot of the mountains on both sides of the valley. Since the rain on the Edom Mountains reaches up to $250-300 \mathrm{~mm} / \mathrm{yr}$ (compared to $\sim 50 \mathrm{~mm} / \mathrm{yr}$ in the Negev), the fans that developed in the eastern foothills of the valley are much bigger in size. The Arava, which is part of the SyrianAfrican Rift Valley and is a rapidly subsiding basin, is $165 \mathrm{~km}$ long and 5-15 km wide, stretching between the Dead Sea and the Gulf of Elat (the Red Sea). Its northern edge (the Dead Sea area) is the lowest place on earth ( $425 \mathrm{~m}$ below sea level).

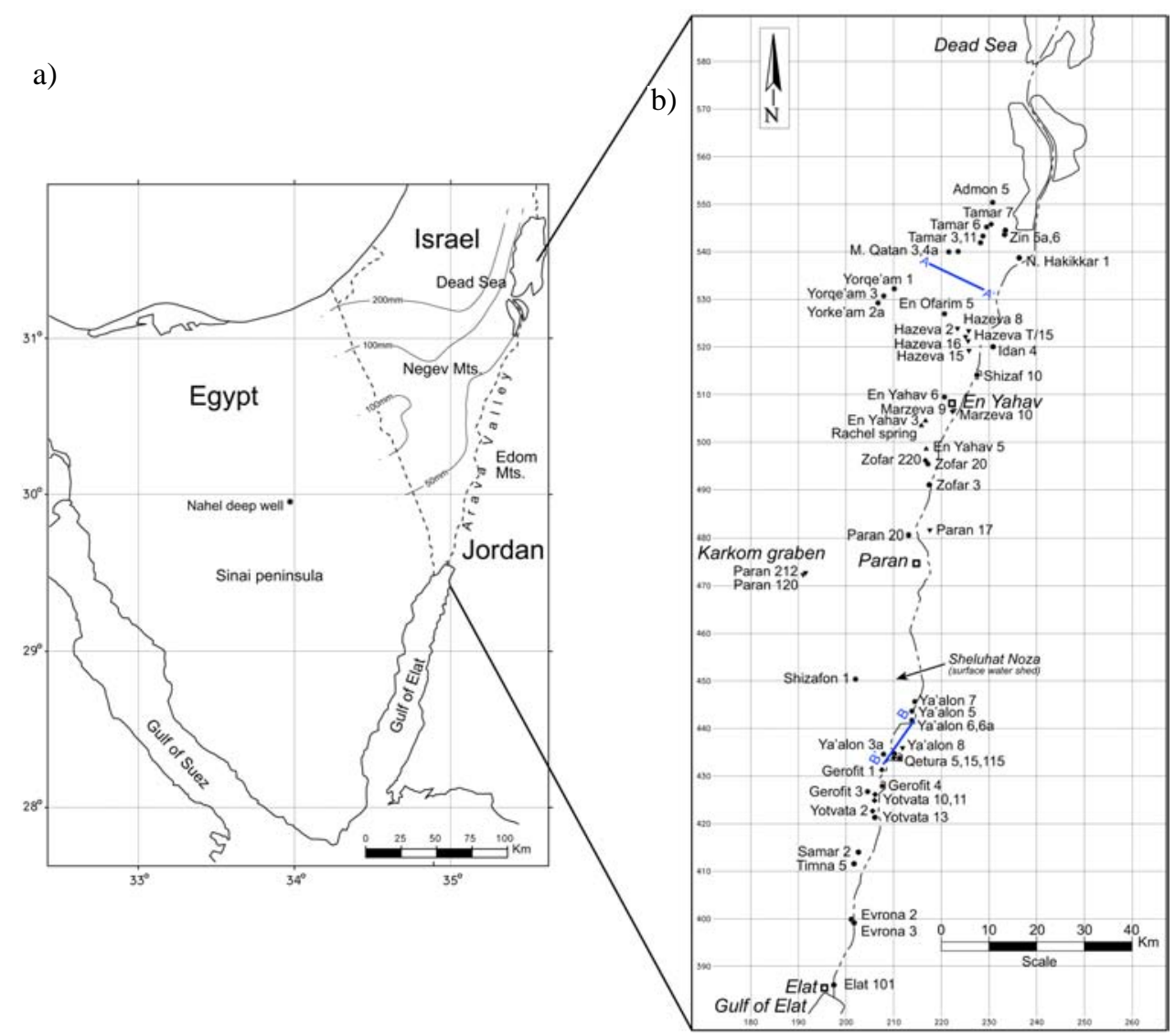

Figure 1 (a) A general map of Sinai and the Negev. Isohyets of mean annual rainfall in the Negev and Arava are from Greenbaum et al. (2001). (b) A location map of the sampled wells along the Arava Valley and in the Negev. Lines A-A' and B-B' mark the location of the geological cross-sections presented in Figure 2.

The area is characterized by short winters with very low precipitation, followed by extremely hot summers with temperatures reaching over $40{ }^{\circ} \mathrm{C}$. The evaporation potential is very high, up to $5000 \mathrm{~mm} / \mathrm{yr}$ (Rosenthal et al. 1990). The rain decreases from $\sim 50 \mathrm{~mm} / \mathrm{yr}$ in the northern part of the valley (Figure 1a) to $<25 \mathrm{~mm} / \mathrm{yr}$ in its southern tip. In central Sinai, it is $40 \mathrm{~mm} / \mathrm{yr}$ (Abed El Samie 
${ }^{14}$ C Variability in Groundwater in Arava Valley, Israel

and Sadek 2001). The direct rainfall on the outcrops contributes negligible replenishment to the groundwater. The rains, which occur during a very few periods, cause torrential flash floods in the major streams. The valley serves as the drainage basin for these occasional flash floods as well as for groundwater flow from both east and west. In the Arava Valley itself, the floods flow to both its tips, the Dead Sea in the north and the Red Sea in the south. The Arava water divide is located in the highest topographic point in the valley (Sheluhat Noza, Figure 1b). Some of the floodwaters recharge the shallow unconsolidated sediments in the valley (Dahan et al. 2007).

Several settlements are situated along the Arava Valley, all economically based on local agriculture using mostly groundwater. Expansion of the agricultural fields and growth of human resources in the last few decades have led to a gradual increase in water supply mainly from wells and, as a result, to some drop in water levels due to overpumping and to vast contamination of the shallow aquifers beneath the agricultural fields (Oren et al. 2004).

\section{Hydrogeology}

The elongated Arava Valley is bordered along both sides by complicated fault systems that separate the thick, young (Neogene to recent) alluvial sediments in its subsiding central part from the much older geological units. This faulted system locates different aquifers opposite each other (Figure 2), a situation that enables water transfer from one aquifer to another and mixing in the Arava Valley of groundwater of different origins, each with its own chemical and isotopic characteristics (Adar et al. 1992; Yechieli et al. 1992).

There are several aquifers in the Arava Valley and its surroundings (Figure 2). Those outside the valley are mostly deep (deeper than $500 \mathrm{~m}$ ) and contain mainly fossil water (Issar 1985), while the aquifers in the valley itself are much shallower (50-200 m) and their water ages are variable and not fully known. These shallow aquifers supposedly contain a mixture of fossil and recent waters as well as contributions of modern irrigation water (Oren et al. 2004; Shalev et al. 2012).

The deep and regional aquifers in the Negev region are of the Lower Cretaceous Kurnub Group, comprised mainly of sandstone, and the overlying Upper Cretaceous Judea Group, consisting of carbonate rocks (limestone, dolomite, and marl). The 2 aquifers in most cases are hydrologically separated by impervious beds at the base of the Judea Group, as evident from differences in water tables and in the chemical and isotopic compositions (Rosenthal et al. 1990; Guttman et al. 1999). The Kurnub aquifer is confined in most of the Sinai and Negev territories, while the Judea aquifer is confined in the synclines and is phreatic in the rest of the area (Guttman et al. 1999). The present recharge to the Kurnub aquifer is negligible compared to its huge storage; recharge presumably took place on its exposures in Sinai and the Negev in ancient times under a more humid climate (Shiftan 1961; Issar et al. 1972). Issar (1985) evaluated the amount of fossil water in the Kurnub Group below Sinai and the Negev to be 200 billion $\mathrm{m}^{3}$. Abed el Rahman (2001) estimated it to be 299 billion $\mathrm{m}^{3}$. The Judea Group aquifer, although containing fossil water, is assumed to be recharged through floods flowing over its outcrops (Arad and Kafri 1980). The transition of floodwater to the aquifer through the main watercourses in the western Arava (Paran, Neqarot, Zin), followed by an assessment of the average contribution to the aquifer, was presented by Ben Zvi and Shentsis (2001). The general flow direction in both aquifers is from the Sinai Peninsula eastward towards the Arava Valley (Issar et al. 1972; Gat and Issar 1974; Issar 1985), with major outlets in the alluvial fill south of the Dead Sea and in the alluvium north of the Red Sea (Rosenthal et al. 2007). The flow towards the Arava is controlled by the geological structures of the Negev as well as by facies changes and by the fault systems that divert the flow contour lines (Rosenthal et al. 1998, 2007; Guttman et al. 1999). 

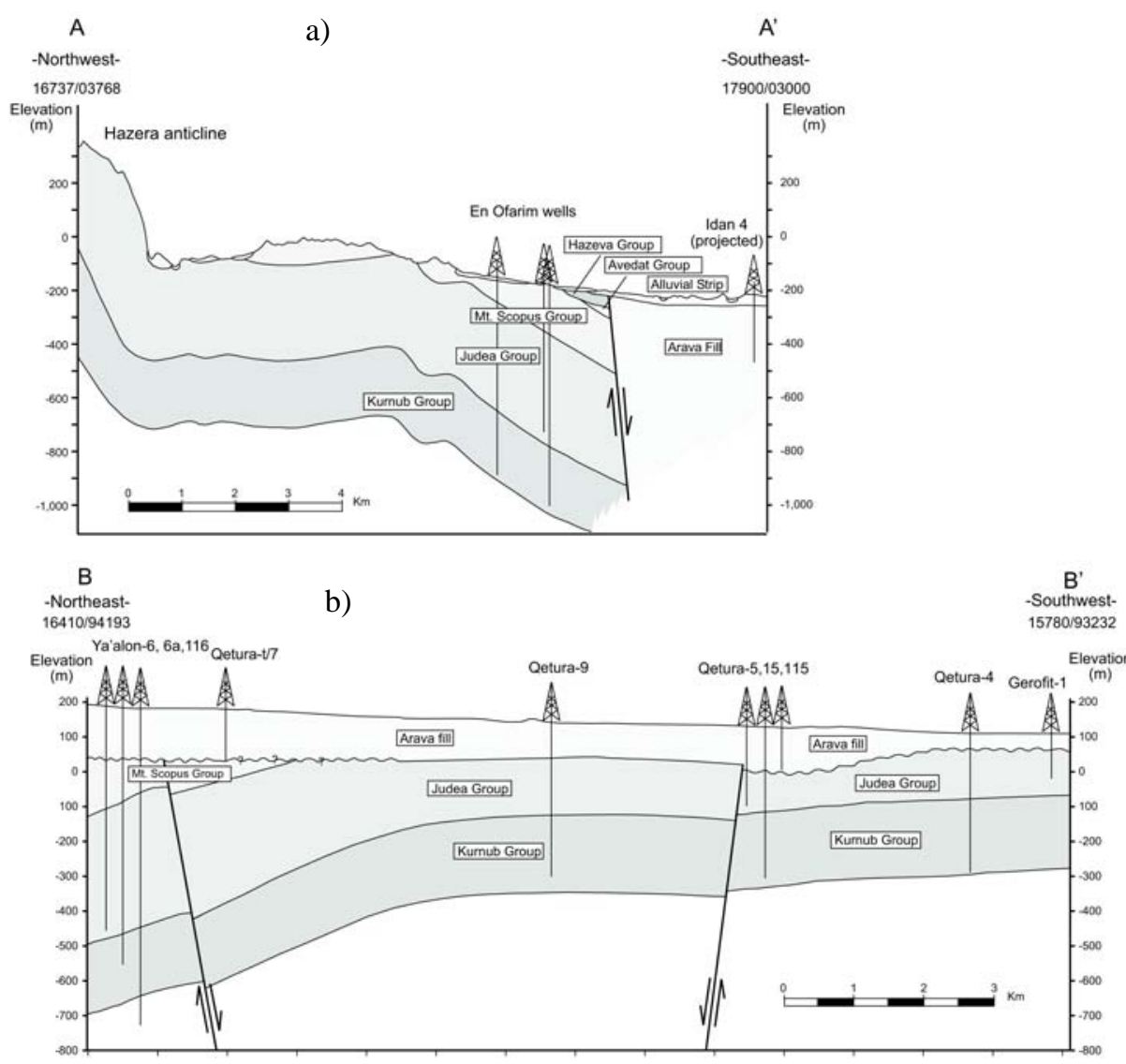

Figure 2 (a) Geological cross-section in the northern Arava Valley (line A-A' in Figure 1b) illustrating: 1) the relationships between the main hydrogeological units; and 2) the contact between the regional aquifers and the shallow Arava Valley aquifers. Also shown are wells drilled to some of those aquifers. (b) Geological crosssection in the southern Arava Valley (line B-B' in Figure 1b) illustrating the relationships between the main hydrogeological units. Also shown are wells drilled in some of the aquifers.

The Mishash Formation, which is part of the Upper Cretaceous Mount Scopus Group that overlies the Judea Group, is an aquifer of limited extension, located east of the central Arava Valley (Guttman et al. 1999). This aquifer is built mainly of fractured chert alternating with chalk and phosphorite and is utilized by only a few wells. The flow in the Mishash aquifer is from its restricted outcrops in the eastern Negev to the Arava Valley. The source of water to this aquifer is still ambiguous. The Mishash aquifer supplies groundwater to several small springs in the central Arava (Yechieli 1987; Bein et al. 1995), one of which is the Rachel spring, which was sampled for ${ }^{14} \mathrm{C}$ analysis in this work.

The shallow aquifers in the valley are built by the Neogene Hazeva Group, which consists of sandstone and clayey layers, and the Alluvial aquifer of Pliocene-Quaternary age, comprised mainly of gravel layers with different degrees of cementation and some interlayers of fine-grained material. The Alluvial aquifer is further divided into 2 main units: the Arava Fill, which is located within the valley, and the Alluvial Strip, which is shallow and situated in the current floodplain of the Arava stream (see Figure 2a). The structure of the Alluvial aquifer is variable and characterized by lenses and interfingering, followed by frequent lateral facies changes forming subaquifers of limited areal extension. The main present recharge to the shallow aquifers is directly through frequent floods flow- 
${ }^{14}$ C Variability in Groundwater in Arava Valley, Israel

ing to the low Arava land from the high mountains on both sides of the valley as well as from lateral subsurface flow generated in the mountains (Gat and Galai 1982; Rosenthal et al. 1990; Adar et al. 1992). There is a greater potential for eastern recharge since the rainfall amount on the Edom Mountains is considerably greater than that in the Negev (250-300 vs. $<50 \mathrm{~mm} / \mathrm{yr}$; Greenbaum et al. 2001; Rosenthal and Bein 2001). Two more sources for the shallow aquifers are the waters in the regional aquifers west of the Arava that flow across the marginal faults and mix with groundwater in the Arava (Adar et al. 1992; Yechieli et al. 1992) and some irrigation return flow from the cultivated fields.

The general direction of groundwater flow in the shallow aquifers in the northern part of the Arava Valley is NNE towards the Dead Sea basin, while in the southern part it is SSW towards the Red Sea (Kroitoru et al. 1981; Guttman et al. 1999). The Hazeva Group sediments are also found outside of the Arava in smaller structures, such as the Karkom graben in the central elevated Negev (Figure 1b). The Karkom graben is an inland arid basin located upstream from the Arava Valley. The Hazeva Group sediments in the graben serve as a local aquifer used for water supply.

The chemistry and the isotopic composition of the groundwater in the Arava and in the surrounding regional aquifers has been investigated in many studies (e.g. Issar et al. 1972; Gat and Issar 1974; Kroitoru 1980; Issar 1982, 1985; Mazor 1985; Rosenthal et al. 1990, 1992, 1998, 2007; Yechieli et al. 1992, Guttman et al. 1999; Vengosh et al. 2007). Most of the water is brackish to saline, although evidence for brines was found in deeper parts of the valley. The relatively low quality of the water requires treatment before supply. In a few places, such as the Karkom graben, water of higher quality was found. Generally, groundwater recharged by floods is of better quality compared to that of fossil and deeper water bodies.

The differences in the water chemistry and especially the distinct isotopic compositions of the water sources helped in tracing hydrological processes such as mixing, connections between aquifers, and flow directions (e.g. Gat and Galai 1982; Kronfeld et al. 1992; Naor et al. 2004; Vengosh et al. 2007). The above studies did not focus much attention to groundwater dating methods ( ${ }^{14} \mathrm{C}$ and tritium) as another useful hydrological tracer. This article attempts to partly close this gap.

\section{METHODS}

Groundwater samples were collected from wells throughout the Negev, including the Arava Valley and the Karkom graben, mostly during 1995 . Electrical conductivity (EC), temperature, $\mathrm{pH}$, and dissolved oxygen (DO) were measured in the field. Analyses were done for water chemistry, stable isotopes, ${ }^{14} \mathrm{C}$ activity, and tritium concentration. All relevant results are presented in Table 1; the rest of the chemical data are given in Bein et al. (1995) and Yechieli et al. (1997). Table 1 includes also values from the literature (see table for list of references) as well as some unpublished analyses. All sampling sites are presented in Figure 1b.

${ }^{14} \mathrm{C}$ analyses were conducted using the conventional method. $\mathrm{BaCl}_{2}$ solution was added to the samples in the field, together with $\mathrm{NaOH}$, in order to precipitate the carbonates. Some $~ 90-100 \mathrm{~L}$ of sample were collected. The precipitated Ba-carbonate from the field was treated with acid to obtain the $\mathrm{CO}_{2}$ for the ${ }^{14} \mathrm{C}$ and $\delta^{13} \mathrm{C}$ analyses. The samples were analyzed for ${ }^{14} \mathrm{C}$ activities at the Weizmann Institute in Rehovot using a LKB 1220 Quantulus ${ }^{\mathrm{TM}}$ scintillation counter, and for $\delta^{13} \mathrm{C}$, at the Geological Survey of Israel using a mass spectrometer. The ${ }^{14} \mathrm{C}$ results are reported as percent modern carbon (pMC), with an average $1 \sigma$ error of $\pm 0.5 \mathrm{pMC}$. Ages quoted are ${ }^{14} \mathrm{C}$ ages (yr BP) and not calendar ages, where the year 1950 is considered the reference year (Stuiver and Polach 1977). The $\delta^{13} \mathrm{C}_{\text {DIC }}$ results are reported as per mil (\%) deviation from the international carbonate standard, NBS$19\left(\delta^{13} \mathrm{C}=+1.95 \mathrm{VPDB}\right)$ with a precision of $\pm 0.1 \%$. 


\section{A Burg et al.}

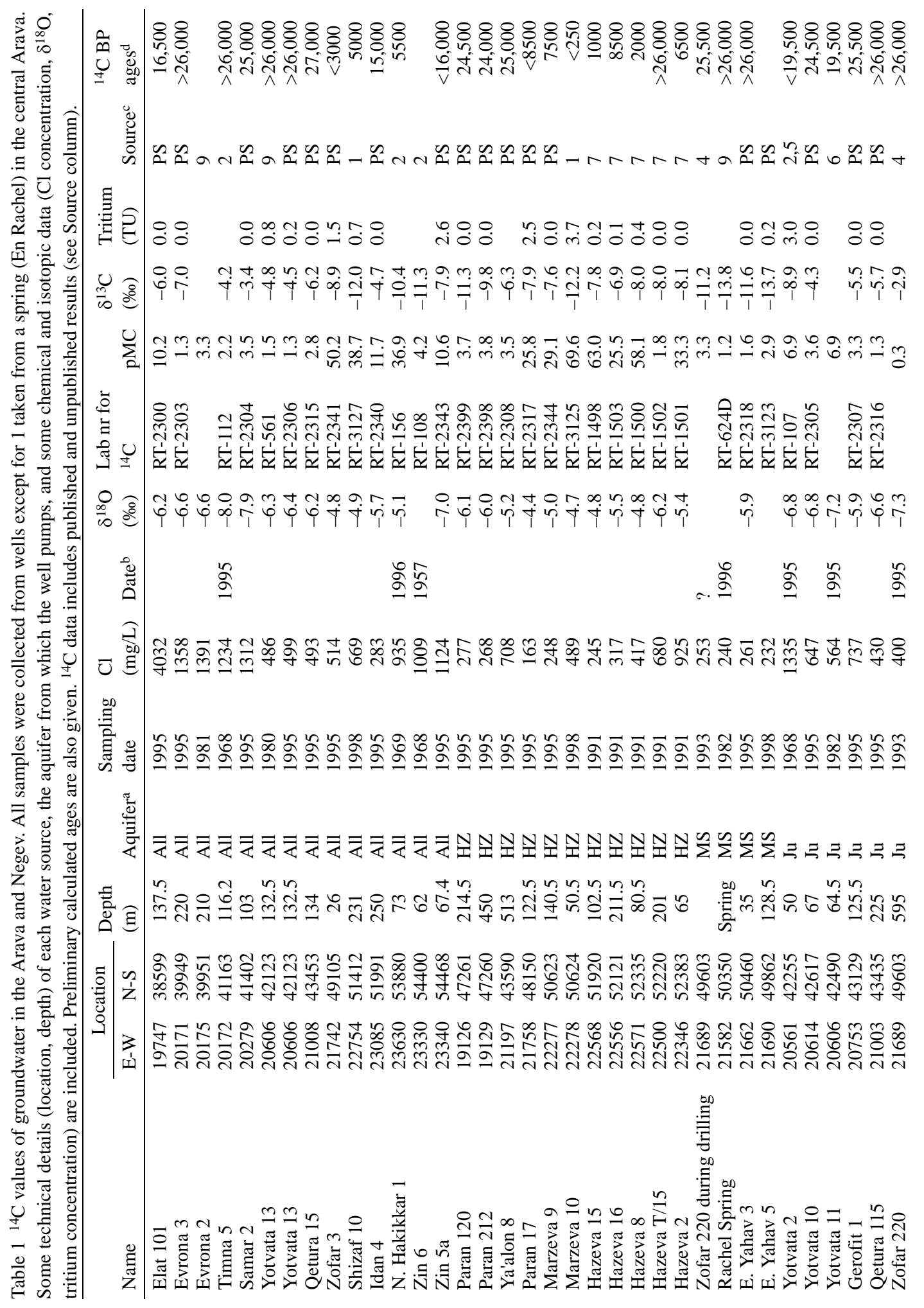


${ }^{14}$ C Variability in Groundwater in Arava Valley, Israel

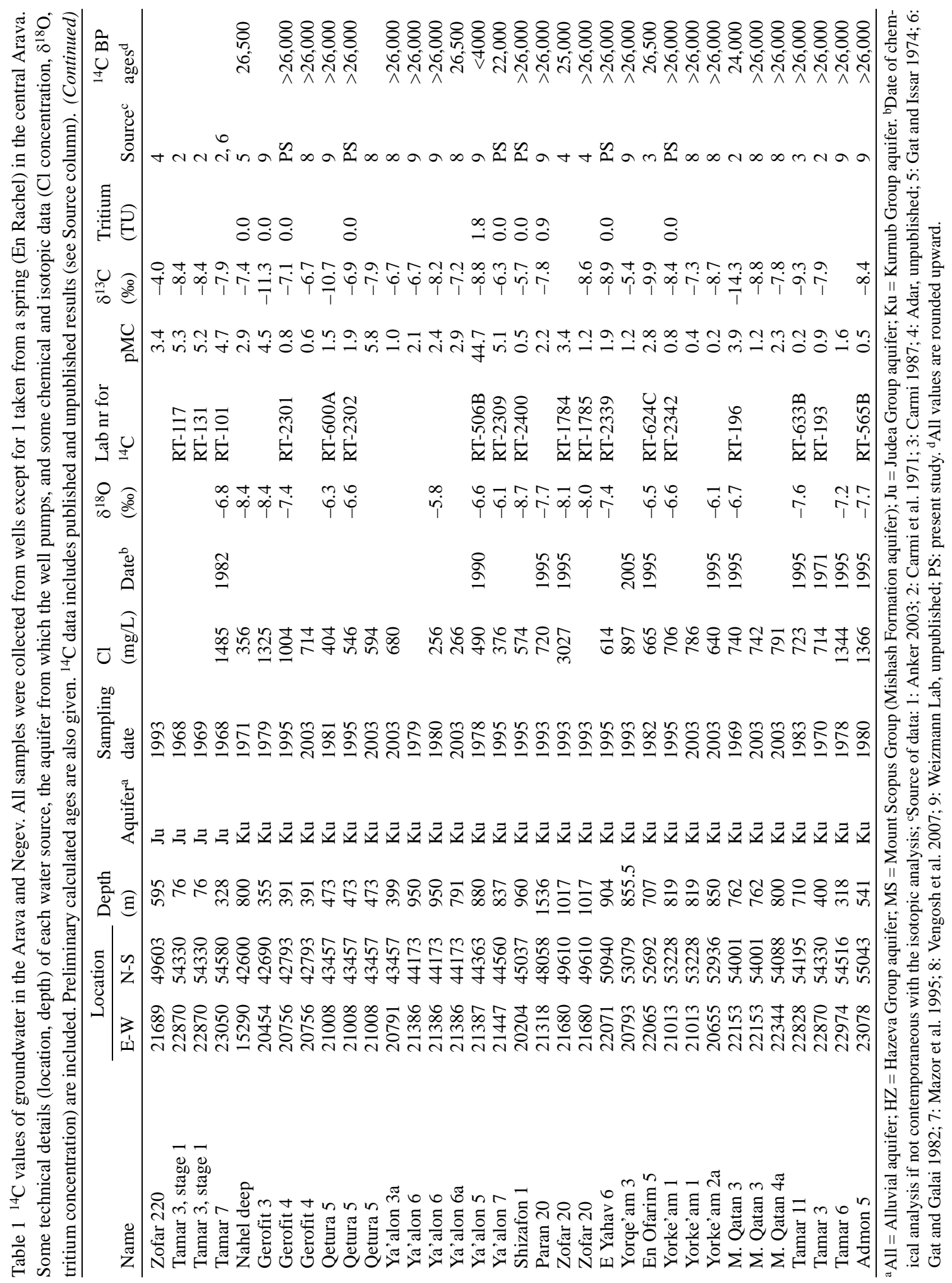




\section{A Burg et al.}

For tritium analyses, water samples were first enriched by electrolysis and then mixed with scintillation liquid and measured in a LKB 1220 Quantulus scintillation counter at the Weizmann Institute. The purpose of the enrichment was to reduce the counting error to $0.3 \mathrm{TU}$ (tritium concentrations are reported in TU units, where $1 \mathrm{TU}$ equals 1 tritium atom out of $10^{18}$ hydrogen atoms).

The $\delta^{18} \mathrm{O}$ of groundwater was measured on VG-SIRA II IRMS and calibrated against the NBS-19 standard in the Geological Survey of Israel. The $\delta^{18} \mathrm{O}$ values are reported as per mil (\%o) deviations from the international standard, V-SMOW (Vienna Standard Mean Ocean Water) with a reproducibility of $\pm 0.1 \%$.

Preliminary ages of most of the samples were calculated through hydrogeochemical modeling by the computer code NETPATH (Plummer et al. 1991), using all available chemical and carbon isotope data. NETPATH first finds all possible net geochemical reactions by which the final groundwater composition is developed from the initial one. The process takes into account minerals and gases along the flow path from the surface to groundwater. For simplicity of this preliminary age determination, reactions involving organic matter were not considered in the NETPATH modeling (most groundwater in the shallow aquifers are oxic, surface water and the uppermost sediments in the Arava are poor in organic matter). Each geochemical reaction model is solved as an isotope-evolution problem, accounting for isotope fractionation along the flow path to predict the isotopic composition at the end point of the reaction, including adjustment of the initial ${ }^{14} \mathrm{C}$ activity to the geochemical reaction (Plummer and Sprinkle 2001).

The chemical composition of the "initial water" from which all samples were developed was taken as the average of 89 samples of floods in the Arava (from Yechieli et al. 2001) and is as follows (values in ppm): $\mathrm{Ca}^{+2}$ 166; $\mathrm{Mg}^{+2}$ 22; $\mathrm{Na}^{+} 83 ; \mathrm{K}^{+} 13 ; \mathrm{Cl}^{-} 138 ; \mathrm{SO}_{4}{ }^{-2}$ 356; $\mathrm{HCO}_{3}{ }^{-} 141 ; \mathrm{NO}_{3}{ }^{-} 16 ; \mathrm{Br}^{-} 1$. The $\delta^{13} \mathrm{C}$ of the $\mathrm{CO}_{2}$ was assumed to be $-18 \%$. Both the $\delta^{13} \mathrm{C}$ and ${ }^{14} \mathrm{C}$ values in the carbonates were set at 0 . The value of $70 \mathrm{pMC}$ in well Marzeva 10 was taken as the initial ${ }^{14} \mathrm{C}$ activity of the water that passed the unsaturated zone (input in NETPATH as "user defined"), since this water sample contains relatively high tritium values, implying recent ages. The value of $\delta^{13} \mathrm{C}$ in the recharging water after passing the unsaturated zone was evaluated at $-12 \%$, similar to the value in the Marzeva 10 well. We assume that $-12 \%$ represents a combined effect of the $C_{3}$ and $C_{4}$ plants, outgassing of soil $\mathrm{CO}_{2}$ and dissolution of some soil carbonates. A few samples that have more depleted $\delta^{13} \mathrm{C}$ values, up to $-14.3 \%$ (Table 1 ), presumably point to a local effect, such as input of organic matter.

The chemical and carbon isotope data from the water sources studied (Table 1) were used as the "final water." Based on available data of the geological setting, surface water evaporation accompanied by both dissolution and precipitation of gypsum, halite, and calcite as well as cation exchange, were all considered as possible geochemical processes for transformation of the initial waters into the final ones. The Rayleigh calculation was taken into account. NETPATH modeling along vertical flow paths ignores mixing portions of water of different ages during horizontal flow.

\section{RESULTS AND DISCUSSION}

This section deals with the ${ }^{14} \mathrm{C}$ results of groundwater in the extremely arid zone of Israel (the Negev Desert and Arava Valley) and their correlated preliminary ages (Table 1), in order to differentiate between waters from the various sources. It is important to note that the ages are defined here as "preliminary" due to the difficulties in determining the exact initial ${ }^{14} \mathrm{C}$ value for each sample, especially because some of the recharge occurred in different times and climates, as well as due to the large variability in the floodwater composition, whose average was taken as the initial value. As stated above, the value of $70 \mathrm{pMC}$ obtained in the Marzeva 10 well was taken as the initial value. 
Similar initial values (65-69 pMC) were previously used by Fridman et al. (1995) for tritium-containing (8 TU) groundwater in the central Negev, for dating a few samples in the Hazeva aquifer in the Arava Valley by Mazor et al. (1995), and for dating several samples from the Kurnub Group aquifer by Vengosh et al. (2007).

There is a recognizable distinction between the ${ }^{14} \mathrm{C}$ values of the deeper and the shallower aquifers (Figure 3), whereby much older preliminary ages were found in the deeper aquifers. This clear distinction between the ${ }^{14} \mathrm{C}$ values in the deeper and shallower aquifers in this arid zone confirms the validity of ${ }^{14} \mathrm{C}$ dating, a conclusion that is not obvious in arid environments, where almost no vegetation occurs and the processes that affect the carbon cycle are theoretically expected to be less pronounced than in temperate areas.

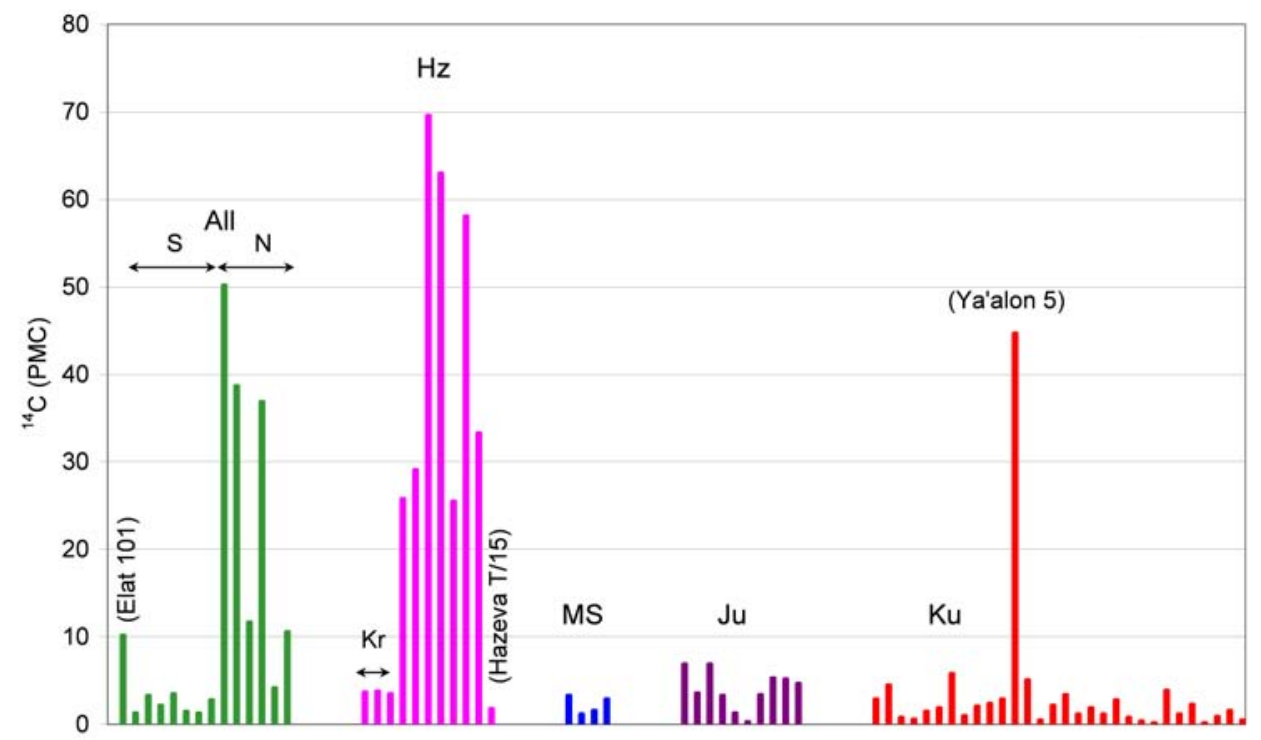

Figure $3{ }^{14} \mathrm{C}$ values in waters from the Negev and Arava, divided according to the main hydrogeological units: All - Alluvium aquifer; S - south Arava; N - north Arava; $\mathrm{Hz}$ - Hazeva Group aquifer; $\mathrm{Kr}$ - Karkom graben; Ms - Mount Scopus Group aquitard-Mishash Formation aquifer; Ju - Judea Group regional aquifer; Ku - Kurnub Group regional aquifer.

$\delta^{13} \mathrm{C}$ values in all aquifers are negative in the range of $-3 \%$ o to $-14 \%$ (Table 1 ), implying that the soil-derived C (value of $\sim-18 \%$; a mixture of $\mathrm{C}_{3}$ and $\mathrm{C}_{4}$ vegetation) and the surrounding carbonate rock-derived $\mathrm{C}$ (value of $\sim 0 \%$ ) are the 2 main sources of the DIC in the water.

\section{Groundwater of the Deeper Aquifers}

The groundwater in the Kurnub and Judea aquifers have low ${ }^{14} \mathrm{C}$ values (usually $<5 \mathrm{pMC}$ ) with negligible tritium contents, implying old ages (see Table 1) and long residence times. Apparent old ages (of $>20,000 \mathrm{yr}$ ) of a few samples from the Kurnub aquifer were previously reported by Issar et al. (1972). Abed El Samie and Sadek (2001) gave ages of up to 23,000 yr ago for water samples from wells in the Sinai Peninsula. It is important to note that the ${ }^{14} \mathrm{C}$ values in most of the Kurnub samples are very close to zero $(<3 \mathrm{pMC})$. We suspect that these values are too low for calculating a specific and precise age and assume that it can be much older than the limit of the ${ }^{14} \mathrm{C}$ dating capability. This difficulty is heightened due to the uncertainty in determining the initial ${ }^{14} \mathrm{C}$ value for each sample, especially because some of the recharge occurred in different paleoclimates. Another factor that 


\section{A Burg et al.}

might hamper the determination of precise ages is the mixing of a few percent of a somewhat younger component (e.g. $10 \%$ of $10 \mathrm{pMC}$ ), which could yield water ages of $30,000 \mathrm{yr}$ ago, while the actual groundwater age is beyond the limit of this dating tool. Because of all these difficulties, every sample in this study (including those in the shallow aquifers) whose ${ }^{14} \mathrm{C}$ value is $<2.5 \mathrm{pMC}$ is estimated to be older than $\sim 26,000$ yr ago (Table 1 ). In some wells with low ${ }^{14} \mathrm{C}$ activities, more than $1{ }^{14} \mathrm{C}$ analysis was done for the same well (Table 1). Differences of up to $3 \mathrm{pMC}$ were detected, again pointing out the sensitivity of the age determination for old water. Some samples of groundwater from the deep aquifers contain $\mathrm{H}_{2} \mathrm{~S}$ and thus may represent overestimated and older ages (maximum age limit) as a result of dissolution of ${ }^{14} \mathrm{C}$-free carbonate minerals during bacterial $\mathrm{SO}_{4}{ }^{-2}$ reduction (Vengosh et al. 2007).

The old ages of the groundwater in the Kurnub aquifer in the Negev and Sinai are in agreement with those found in corresponding aquifers in the Sahara Desert (Knetsch et al. 1962; Munnich and Vogel 1962; Himida 1970; Sonntag et al. 1979; Edmunds and Wright 1979), some of which were estimated to be on the order of even 1 million yr ago (Sturchio et al. 2004). Surprisingly, high ${ }^{14} \mathrm{C}$ and tritium values were measured in 1 well that pumps from the Kurnub aquifer (Ya'alon 5, 44.7 pMC, 1.8 TU, Table 1, Figure 3). These anomalous values imply penetration of younger water from lateral shallower aquifers, which was indeed proven later by technical examination of the well. This case shows the practical aspect of exploring ${ }^{14} \mathrm{C}$ for tracking water sources.

The Kurnub aquifer is characterized by very negative values of $\delta^{18} \mathrm{O}(-7.6 \pm 0.4 \%$ on the average) followed by d-excess $\left(=\delta \mathrm{D}-8 \delta^{18} \mathrm{O}\right)$ of $10 \%$ or less (Gat et al. 1969; Gat and Galai 1982). These values significantly differ from the composition of the current recharge in the Negev and Arava $\left(\delta^{18} \mathrm{O}\right.$ in the Negev precipitation is from $-6 \%$ o up to values more enriched in the heavy species with $15 \%<$ d-excess $<25 \%$, Levin et al. 1980), and from the recharge in the much more rainy regions of central and northern Israel $\left(\delta^{18} \mathrm{O}=-4 \%\right.$ to $-7 \%$ o). The latter is clustered along the Eastern Mediterranean Meteoric Water Line (EMMWL) characterized by d-excess of 22\% (Gat and Galai 1982). The isotopic composition of the Kurnub aquifer is indeed outstanding, thus identified as paleowaters that have been recharged in ancient times, when cooler and wetter climates prevailed in the intake areas (Issar et al. 1972; Gat et al. 1969; Gat and Galai 1982; Arad and Kafri 1980). The $\delta^{18} \mathrm{O}$ values are particularly negative in central Sinai (Nahel deep well, Table 1 and see also Abed El Samie and Sadek 2001, who reported even more depleted $\delta^{18} \mathrm{O}$ values from Sinai of up to $-9.53 \%$ ) and in the central Negev (Shizafon 1 well, with a value similar to that of the Nahel deep well, Table 1). The $\delta^{18} \mathrm{O}$ values become more enriched toward the Arava Valley, indicating mixing with younger water sources, although most of the storage is still of an ancient source. Surprisingly, no correlation between $\delta^{18} \mathrm{O}$ and ${ }^{14} \mathrm{C}$ activities is seen along the flow path within the aquifer. Although no simple explanation can be given for this observation, 2 possible speculations are suggested: (1) transport over long distances from the intake areas in an extremely arid zone followed by some leakage from the overlying Judea aquifer whose water is old enough but of less negative $\delta^{18} \mathrm{O}$ values; and (2) water-rock interactions during the prolonged flow in deeper routes of relatively high temperature, $\mathrm{H}_{2} \mathrm{~S}$ containing, which increased the apparent age.

According to Issar et al. (1972), water in the Judea aquifer shows somewhat younger ages. Our ${ }^{14} \mathrm{C}$ results somehow agree with this although the difference is minor (4.1 pMC on the average in the Judea Group compared to 2.0 pMC in the Kurnub Group, excluding Ya'alon 5). The relatively negative $\delta^{18} \mathrm{O}$ values (although slightly less depleted) in the Judea aquifer indicate that recharge occurred mostly in somewhat similar conditions to that of the groundwater in the Kurnub aquifer during past wet periods. Yet, replenishment to the Kurnub aquifer was on its outcrops in central Sinai only, while recharge to the Judea aquifer occurred also along the flow paths to the east. At 
${ }^{14}$ C Variability in Groundwater in Arava Valley, Israel

present, there is almost no recharge to the Kurnub aquifer in the Negev, but there is some replenishment to the Judea Group along the main watercourses.

\section{Groundwater of the Intermediate Aquifer (Mishash Formation Aquifer)}

Groundwater in the Mishash Formation aquifer (which is part of the Mount Scopus Group aquiclude/aquitard) has low ${ }^{14} \mathrm{C}$ values that correspond to old ${ }^{14} \mathrm{C}$ ages $(<3.3 \mathrm{pMC}$; >25,500 yr ago; Table 1, Figure 3). This value is surprising considering that the Mishash aquifer is quite shallow and potentially has some recharge from nearby outcrops. This can be explained by the following:

1. Lateral leakage of older water from the Judea aquifer;

2. Oxidation of the abundant old organic matter in the Mount Scopus Group $\left(\delta^{13} \mathrm{C}=-28\right.$ to $-29 \%$; Schneider-Mor et al. 2012), which consumes the dissolved oxygen. Indeed, the $\delta^{13} \mathrm{C}$ values measured in the water of this aquifer are quite negative ( -12\%o, Table 1$)$ compared to $-3 \%$ o to $-9 \%$ in the Judea aquifer. Such a process is expected to yield in its final stage apparent lower values of ${ }^{14} \mathrm{C}$ activities;

3. Negligible direct recharge and very slow flow. As a result, the residence time is quite long as reflected in the low ${ }^{14} \mathrm{C}$ and the calculated ages.

\section{Groundwater of the Shallow Aquifers}

Groundwater in the shallow aquifers in the Arava Valley (Alluvium and Hazeva) exhibit a large range of ${ }^{14} \mathrm{C}$ values from 1 to $70 \mathrm{pMC}$ (Table 1 , Figure 3), implying variable ages, including young and even recent ages of some of these waters. This large range confirms again the validity of ${ }^{14} \mathrm{C}$ age determination in extremely arid environments. The variable ages are further supported by the presence of tritium-up to 3.7 TU in many of the samples (Table 1). For comparison, Yechieli et al. (2001) measured only slightly higher values of 4.1-6.0 TU in modern floodwaters in the Arava. A large ${ }^{14} \mathrm{C}$ range was also detected by Mazor et al. (1995), who determined ages of water in 5 samples of the Hazeva aquifer to be 50-7500 yr, with 1 sample of more than 25,000 yr (1.8 pMC in the Hazeva T/15 well, which may already be beyond the limit of the ${ }^{14} \mathrm{C}$ dating method). This exceptionally low ${ }^{14} \mathrm{C}$ value in the Hazeva T/15 well (Table 1, Figure 3) could be because it is the only non-pumping well in our list ( $\mathrm{T}$ is the sign for an observation well) and thus might not represent the real value of the regional groundwater, but rather a response to local factors (e.g. interaction with old organic matter, contamination in the borehole, etc.). Alternatively, it is possible that this well is replenished by ancient water from the adjacent underlying Eocene chalky aquitard.

The sampled wells cover a vast range of depths from 26 to $450 \mathrm{~m}$ (Table 1). A somewhat opposite correlation between depth and ${ }^{14} \mathrm{C}$ activities and tritium concentrations (Figure 4) confirms that shallow permeable layers contain relatively larger amounts of younger water that was recharged from the surface. The youngest water in the Alluvium aquifer is expected to be found in the very shallow Zofar 3 well (26 m depth, Table 1), which was drilled into the Alluvial Strip aquifer. Therefore, based on the relatively high tritium content, the calculated ${ }^{14} \mathrm{C}$ age for this well ( $\sim 3000 \mathrm{yr}$ ago) is suspected to be much too old. It is possible that the initial value of ${ }^{14} \mathrm{C}$ for this well is closer to $50 \mathrm{pMC}$ as a result, for example, of dissolution of old carbonates. This lower value would modify the age of the water to almost a recent one. An alternative explanation for the low ${ }^{14} \mathrm{C}$ value together with the higher tritium content is a mixing of 2 water bodies of different ages in this well, one of which would have been recent. Following this approach, ages of all samples with relatively high tritium content (>1 TU, Zofar 3, Zin 5a, Paran 17, Marzeva 10, Yotvata 2, Ya'alon 5) are estimated to be younger than the ${ }^{14} \mathrm{C}$ calculated age (Table 1 ). The mixing of 2 different-age water bodies is evi- 


\section{A Burg et al.}

dent in the Zin 5a well; the depleted (Kurnub-like) $\delta^{18} \mathrm{O}$ value (-7\%o, Table 1) together with a high tritium content and low ${ }^{14} \mathrm{C}$, as well as higher salinity (1124 $\left.\mathrm{mg} \mathrm{Cl} / \mathrm{L}\right)$ points to such mixing.

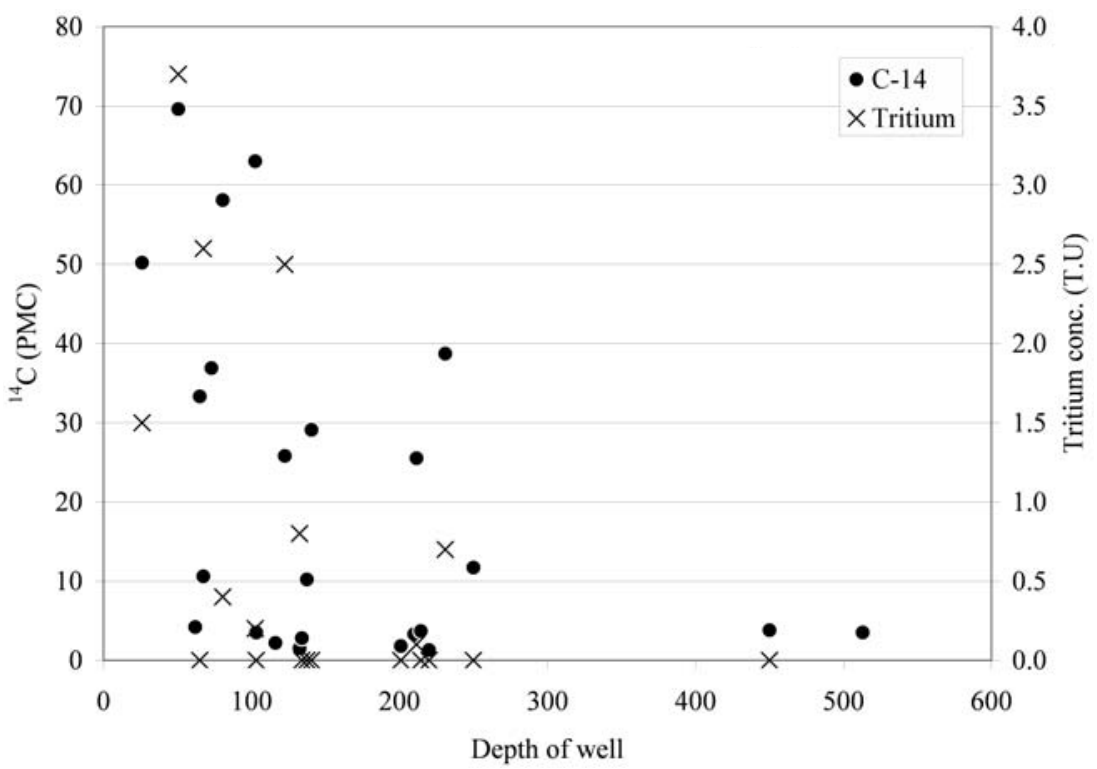

Figure 4 Correlation between depth of the sampled wells in the shallow aquifers (Alluvial and Hazeva aquifers) and their ${ }^{14} \mathrm{C}$ activities and tritium concentrations. The somewhat reverse relationships imply relatively larger discharge of recent water into the shallow permeable layers.

The large variation in ${ }^{14} \mathrm{C}$ values in groundwater of the shallow aquifers (Table 1) indicates weak hydrological connections among the different subaquifers and variable flow rates. Moreover, it implies different amounts of ancient water from the deep regional aquifers that recharge the shallow aquifers (mainly their deeper parts) by lateral flow. This mixing is marked also by a variable range of $\delta^{18} \mathrm{O}$ values since there is a distinction between the 2 main end-members in the Arava: one is $\delta^{18} \mathrm{O}$ and $\delta^{2} \mathrm{H}$ enriched ( $-4 \%$ o to $-6 \%$, $-20 \%$ o to $-35 \%$, respectively [Gat and Issar 1974], or $-5.94 \%$ and $-34 \%$ as found in Bir Baida in Jordan and representing floodwater [Rosenthal et al. 1990]); and the second is $\delta^{18} \mathrm{O}$ and $\delta^{2} \mathrm{H}$ depleted ( -7.8 to $-8.5 \%$ and $<-60 \%$, respectively [Rosenthal et al. 1990], or $\delta^{18} \mathrm{O}=-7.6 \pm 0.4 \%$ [Gat and Galai 1982]). The first end-member, which is dominant in the shallower aquifers, characterizes the present day, ${ }^{14} \mathrm{C}$-enriched recharge derived from recent flash floods and local rain under arid conditions and is thus partly evaporated, while the second end-member is found in the Kurnub Group regional aquifer and represents ancient waters (Gat and Issar 1974; Issar and Gat 1981; Issar 1985). It seems that waters in the shallow aquifers with $\delta^{18} \mathrm{O}$ above $-5.5 \%$ contain larger portions of present-day recharge as seen by the relatively high ${ }^{14} \mathrm{C}$ activities (Figure 5), while waters with $\delta^{18} \mathrm{O}$ below $-5.5 \%$ contain mainly ancient components. In the Timna area of the southern Arava Valley, this complex mixing in the shallow aquifer is present also along the horizontal level; while the eastern part of the aquifer is replenished mainly from floodwater recharging from the Edom Mountains and thus contains relatively fresh water with enriched $\delta^{18} \mathrm{O}$, the western part of the aquifer is dominated by water entering from the regional aquifers in the west and characterized by depleted $\delta^{18} \mathrm{O}$ and much higher salinity.

There is a marked difference in ${ }^{14} \mathrm{C}$ values in the Alluvium aquifer between the northern and southern parts of the Arava Valley (Figure 3). The northern part exhibits a varied composition, some with 


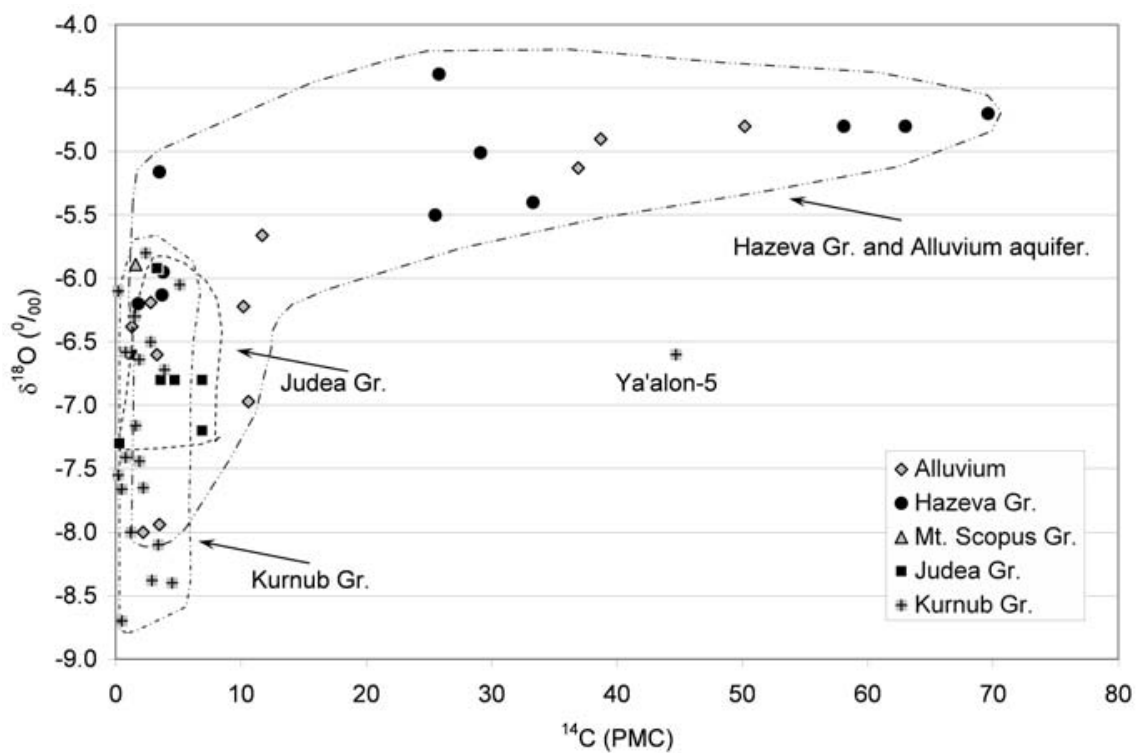

Figure 5 Correlation between ${ }^{14} \mathrm{C}$ and $\delta^{18} \mathrm{O}$ for all aquifers in the Negev and Arava. Each aquifer is marked by a circled area that includes all its measured values.

high values, while the southern part is characterized by lower ${ }^{14} \mathrm{C}$ values and is more homogeneous, reflecting 2 influencing trends: (1) the geographic decrease in precipitation southward (Figure 1a) or the increasing aridity, e.g. fewer flood events from the Negev regions in the south, less direct recharge and longer residence time; and (2) a larger contribution in the southern Arava of ancient, more saline, $\delta^{18} \mathrm{O}$-depleted water from the regional aquifers to the entire section of the shallow aquifers. A somewhat higher ${ }^{14} \mathrm{C}$ value was detected in the most southern Elat 101 well (10.2 pMC; Table 1, Figure 3). This can be explained by a larger contribution of floodwater from the huge watercourse of Wadi El-Yetem, which collects water from vast areas in the Edom Mountains and flows into the southernmost part of the Arava Valley.

The low ${ }^{14} \mathrm{C}$ values in the Hazeva aquifer in the Karkom graben (Figure 3), as seen in the Paran 120 , 212 wells (Figure $1 \mathrm{~b})$, indicate an apparent old age ( 24,000 yr ago, Table 1$)$. This result implies a low recharge rate compared to the large reservoir and/or a lateral inflow of regional ancient water from the Judea and Kurnub aquifers. The zero tritium concentrations (Table 1) as well as the depleted $\delta^{18} \mathrm{O}$ value support both options; the present-day precipitation in this higher region of the Negev is somewhat depleted (-6.5\%o, Levin et al. 1980), compared to the lower parts of the Negev Desert.

\section{CONCLUSIONS}

The results of our study confirm that ${ }^{14} \mathrm{C}$ can serve as a hydrological tracer in arid environments, although a better perspective on the regional hydrological system is achieved when combined with other tracers, such as the $\mathrm{O}$ and $\mathrm{C}$ stable isotopes, salinity, and tritium concentrations. The large gaps between ${ }^{14} \mathrm{C}$ values in the different aquifers in the arid region of southern Israel were used to enhance our understanding of the underground flow regime and rates, particularly the complex connections between the different aquifers and the mixing of water bodies. In addition, it was demonstrated that the ${ }^{14} \mathrm{C}$ values can even help in solving practical issues such as identifying technical failures in a well. 


\section{A Burg et al.}

The presence of high ${ }^{14} \mathrm{C}$ values in groundwater in this arid zone confirms that ${ }^{14} \mathrm{C}$ age calculation is indeed feasible (although not completely accurate) in extremely arid environments, where almost no vegetation occurs and thus the processes that affect the carbon cycle are theoretically expected to be different and less pronounced than in temperate areas. It seems, however, that the initial ${ }^{14} \mathrm{C}$ value in the arid region of Israel resembles that of the Mediterranean climate zone.

\section{ACKNOWLEDGMENTS}

We wish to thank Dr Amos Bein, our colleague in the sampling campaign, Israel Carmi, emeritus of the Weizmann Institute for the ${ }^{14} \mathrm{C}$ and tritium analysis and for providing unpublished data given in this paper, the Geochemical Division staff in the GSI for the chemical and the stable isotope results, Prof Eilon Adar from the Zuckerberg Institute, Water Research, Ben-Gurion University of the Negev, for providing his unpublished ${ }^{14} \mathrm{C}$ results, and Bevie Katz for proofreading. Finally, we thank the anonymous reviewer for improving the manuscript.

\section{REFERENCES}

Abed el Rahman H. 2001. Evaluation of groundwater resources in Lower Cretaceous aquifer system in Sinai. Water Resources Management 15:187-202.

Abed el Samie SG, Sadek MA. 2001. Groundwater recharge and flow in the Lower Cretaceous Nubian Sandstone aquifer in the Sinai Peninsula, using isotopic techniques and hydrochemistry. Hydrogeolgy Journal 9:378-89.

Adar EM, Rosenthal E, Issar AS, Batelaan O. 1992. Quantitative assessment of the flow pattern in the southern Arava Valley (Israel) by environmental tracers and a mixing cell model. Journal of Hydrology 136:333-52.

Anker Y. 2003. The evolution of the carbonate system in hyper-arid environments (Central Arava area, Israel), and its implication for ${ }^{14} \mathrm{C}$ groundwater dating. Israel Geological Survey, Report GSI/19/03. 107 p. In Hebrew with English abstract.

Arad A, Kafri U. 1980. Hydrogeological inter-relationship between the Judea Group and the Nubian sandstone aquifers in Sinai and in the Negev. Israel Journal of Earth Sciences 29:67-72.

Bein A, Yechieli Y, Halicz L. 1995. Geochemistry of groundwater in the southern Arava valley. Israel Geological Survey, Report GSI/43/95. 28 p. In Hebrew.

Ben Zvi A, Shentsis I. 2001. Assessment of runoff as a component of water resources in the Negev and Arava. Israel Journal of Earth Sciences 50:61-70.

Carmi I. 1987. Rehovot radiocarbon measurements III. Radiocarbon 29(1):100-14.

Carmi I, Noter Y, Schlesinger R. 1971. Rehovot radiocarbon measurements I. Radiocarbon 13(2):412-9.

Clark ID, Fritz P. 1997. Correction for carbonate dissolution. In: Environmental Isotopes in Hydrogeology. New York: Lewis Publishers. p 206-13.

Dahan O, Shani Y, Enzel Y, Yechieli Y, Yakirevich A. 2007. Direct measurements of floodwater infiltration into shallow alluvial aquifers. Journal of Hydrology 344:157-70.
Edmunds WM, Wright EP. 1979. Groundwater recharge and palaeoclimate in the Sirte and Kufra basins, Libya. Journal of Hydrology 40:215-41.

Fontes JC. 1983. Dating of groundwater. In: Guidebook of Nuclear Techniques in Hydrology. Technical Report No. 91. Vienna: IAEA. p 285-317.

Fridman V, Mazor E, Becker A, Avraham D, Adar E. 1995. Stagnant aquifer concept Part 3. Stagnant miniaquifers in the stage of formation, Makhtesh Ramon, Israel. Journal of Hydrology 173:263-82.

Gat JR, Mazor E, Tzur Y. 1969. The stable isotope composition of mineral waters in the Jordan Rift Valley, Israel. Journal of Hydrology 7:334-52.

Gat JR, Issar A. 1974. Desert isotope hydrology: water sources of the Sinai Desert. Geochimica et Cosmochimica Acta 38:1171-31.

Gat JR, Galai A. 1982. Groundwaters of the 'Arava Valley: an isotopic study of their origin and interrelationships. Israel Journal of Earth Sciences 31:25-38.

Greenbaum N, Enzel Y, Schick AP. 2001. Magnitude and frequency of paleofloods and historical floods in the Arava basin, Negev Desert, Israel. Israel Journal of Earth Sciences 50:159-86.

Guttman Y, Burg A, Lifshitz A, Lumelsky S, Zukerman H. 1999. Hydrological model for estimation of water potential in the Arava aquifers - final report. Tahal Company, Report 6127-d99.201. 52 p. In Hebrew.

Himida IH. 1970. The Nubian Artesian Basin, its regional hydrogeological aspects and palaeohydrogeological reconstruction. Journal of Hydrology 9:89116.

Issar AS. 1982. A composite cumulative chemical and isotope data diagram as a tool in hydrochemical investigation. In: Proceedings, 3rd Seminar on Hydrogeology. Lisbon. p 190-200.

Issar AS. 1985. Fossil water under the Sinai-Negev Peninsula. Scientific American 253(1):82-8.

Issar A, Bein A, Michaeli A. 1972. On the ancient water of the Upper Nubian sandstone aquifer in central Sinai 


\section{${ }^{14} \mathrm{C}$ Variability in Groundwater in Arava Valley, Israel}

and southern Israel. Journal of Hydrology 17:353-74.

Issar A, Gat J. 1981. Environmental isotopes as a tool in hydrogeological research in an arid basin. Ground Water 19(5):490-4.

Knetsch G, Shata A, Munnich KO, Vogel JC, Shazly MM. 1962. Untersuchungen an groundwasser der OstSahara. Geologische Rundschau 52:587-610.

Kroitoru L. 1980. The hydrogeology of the Nubian sandstone in southern Israel (lower Cretaceous) [MSc thesis]. Tel-Aviv University. In Hebrew with English abstract.

Kroitoru L, Kronfeld J, Ginzburg A. 1981. The geohydrology of the Gerofit-Ya'alon area. Israel Journal of Earth Sciences 30:24-30.

Kroitoru L, Carmi I, Mazor E. 1989. Groundwater ${ }^{14} \mathrm{C}$ activity as affected by initial water-rock interactions in the Judean Mountains, Israel. Chemical Geology 79: 259-74.

Kronfeld J, Weinberger G, Yaniv A, Zafrir H, Vulcan U, Agami M, Rosenthal E. 1992. Uranium isotope disequilibrium studies and the geohydrology of the Arava Rift Valley, Israel. Nuclear Geophysics 6(4):535-45.

Levin M, Gat JR, Issar A. 1980. Precipitation, flood- and groundwaters of the Negev highlands: an isotopic study of desert hydrology. Arid-Zone Hydrology: Investigation with Isotope Techniques. IAEA-AG-158/ 1. Vienna: IAEA. p 3-22.

Mazor E. 1985. Mixing in natural and modified groundwater systems: detection and implications on quality and management. In: Scientific Basis for Water Resources Management. Proceedings of the Jerusalem Symposium, International Association of Hydrological Sciences Publication 153. p 193-251.

Mazor E, Gilad D, Fridman V. 1995. Stagnant aquifer concept Part 2. Small scale artesian systems - Hazeva, Dead Sea Rift Valley, Israel. Journal of Hydrology 173:241-61.

Mook WG. 1980. Carbon-14 in hydrogeological studies. In: Fritz P, Fontes JC, editors. Handbook Of Environmental Isotope Geochemistry 1: the Terrestrial Environment. New York: Elsevier. p 49-74.

Munnich KO, Vogel JC. 1962. Untersuchungen an pluvialen wassern der Ost-Sahara. Geologische Rundschau 52:611-24.

Naor H, Granit Y, Zurieli A, Burg A. 2004. Southern Arava - updating of the hydrological and geochemical state of the aquifers and boreholes for the year 2003, operational forecast for 2007 and recommendations for new boreholes. Tahal Company, Report 15046d04.173. 62 p. In Hebrew.

Oren O, Yechieli Y, Bohlke JK, Dody A. 2004. Contamination of groundwater under cultivated fields in an arid environment, central Arava Valley, Israel. Journal of Hydrology 290:312-28.

Plummer LN, Prestemon EC, Parkhurst DL. 1991. An interactive code (NETPATH) for modeling NET geochemical reactions along a flow PATH. US Geological Survey, Water-Resources Investigations, Re- port 91-4078. $227 \mathrm{p}$.

Plummer LN, Sprinkle CL. 2001. Radiocarbon dating of dissolved inorganic carbon in groundwater from confined parts of the Upper Floridan aquifer, Florida, USA. Hydrogeology Journal 9:127-50.

Rosenthal E, Adar E, Issar AS, Batelaan O. 1990. Definition of groundwater flow patterns by environmental tracers in the multiple aquifer system of southern Arava Valley, Israel. Journal of Hydrology 117:33968.

Rosenthal E, Weinberger G, Berkowitz B, Flexer A, Kronfeld J. 1992. The Nubian sandstone aquifer in central and northern Negev, Israel: delineation of hydrogeological model under conditions of scarce data. Journal of Hydrology 132:107-35.

Rosenthal, E, Jones BF, Weinberger G. 1998. The chemical evolution of Kurnub Group paleowater in the Sinai-Negev province - a mass balance approach. Applied Geochemistry 13:553-69.

Rosenthal E, Bein A. 2001. The Arava Rift Valley (Dead Sea Transform) - an interdisciplinary approach to assess available water resources of an arid basin. Israel Journal of Earth Sciences 50:49-52.

Rosenthal E, Zilberbrand M, Livshitz Y. 2007. The hydrochemical evolution of brackish groundwater in central and northern Sinai (Egypt) and in the western Negev (Israel). Journal of Hydrology 337:294-314.

Schneider-Mor A, Alsenz H, Ashckenazi-Polivoda S, Illner P, Abramovich S, Feinstein S, Almogi-Labin A, Berner Z, Puttmann W. 2012. Paleoceanographic reconstruction of the late Cretaceous oil shale of the Negev, Israel: integration of geochemical, and stable isotope records of the organic matter. Palaeogeography, Palaeoclimatology, Palaeoecology 319-320:46-57.

Shalev N, Gavrieli I, Lazar B, Burg A. 2012. Groundwater contamination by agriculture activities in arid environment: evidence from nitrogen and oxygen isotopic composition, Arava Valley, Israel. In: Hydrogeology of Arid Environments, Proceedings. Poster abstract. Stuttgart. p 271.

Shiftan ZL. 1961. New data on the artesian aquifers of the southern Dead Sea Basin and their geological evolution. Bulletin of the Research Council of Israel 10G(1-2):267-91.

Sonntag C, Klitzsch E, Lohnert EP, El-Shazly EM, Munnich KO, Junghans C, Thorweihe U, Weistroffer K, Swailem FM. 1979. Palaeoclimatic information from deuterium and oxygen-18 in carbon-14-dated North Saharian groundwaters; groundwater formation in the past. In: Proceedings of the International Symposium on Isotope Hydrology, Neuherberg, 1978. Volume 2. Vienna: IAEA. p 569-81.

Stuiver M, Polach HA. 1977. Discussion: reporting of ${ }^{14} \mathrm{C}$ data. Radiocarbon 19(3):355-63.

Sturchio NC, Du X, Purtschert R, Lehmann BE, Sultan M, Patterson LJ, Lu ZT, Muller P, Bigler T, Bailey K, O’Connor TP, Young L, Lorenzo R, Becker R, El Alfy Z, El Kaliouby B, Dawood Y, Abdallah AMA. 2004. 


\section{A Burg et al.}

One million year old groundwater in the Sahara revealed by krypton-81 and chlorine-36. Geophysical Research Letters 31: L05503, doi:10.1029/ 2003 GL019234.

Vengosh A, Hening S, Ganor J, Bernhard M, Weyhenmeyer CE, Bullen TD, Paytan A. 2007. New isotopic evidence for the origin of groundwater from the Nubian Sandstone aquifer in the Negev, Israel. Applied Geochemistry 22:1052-73.

Vogel JC. $1970 .{ }^{14} \mathrm{C}$ dating of groundwater. In: Isotope Hydrology. Vienna: IAEA. p 225-34.

Yechieli Y. 1987. The geology of the northern Arava Valley and Mahmal anticline, Hazeva region [MSc thesis]. The Hebrew University. Israel Geological Sur- vey, Report GSI/30/87, 94 p. In Hebrew with English abstract.

Yechieli Y, Starinsky A, Rosenthal E. 1992. Evolution of brackish groundwater in a typical arid region: northern Arava Rift Valley, southern Israel. Applied Geochemistry 7(4):361-74.

Yechieli Y, Bein A, Halicz L. 1997. Geochemistry of groundwater in the central Arava Valley. Israel Geological Survey, Report GSI/30/96. 10 p. In Hebrew.

Yechieli Y, Bein A, Burg A, Yarom I. 2001. The impact of flash flood interception on the Arava shallow groundwater: characterization of the interrelationships in the natural and disturbed systems. Israel Geological Survey, Report TR-GSI/11/2001. 15 p. In Hebrew. 